\title{
Begriffsverdrängung and Freedom of Religion. Notes on interpretation in private law
}

Begriffsverdrängung y Libertad de Religión. Notas sobre interpretación en derecho privado.

\author{
Salvatore Tolone Azzariti \\ Professor of Civil Law, Oxford University, University of Buenos Aires \\ and University de Palermo. \\ City: Naples/Oxford \\ Country: Italy/United Kingdom \\ Original article (research) \\ RFJ, No. 7, 2020, pp. 90-108, ISSN 2588-0837
}

\begin{abstract}
Religious exemption in the United States is briefly analyzed by the effects of its conceptual lack on the system and its operational field. The application in private law, as a phase of the interpretation that develops control over the effects of the norm. Then the taxonomy of the fields further highlights these effects at a systematic level. The Private Law approach allows us to demonstrate the conceptual displacement that is generated by the First Amendment concerning other application fields and the classificatory function that, about the exemption, can be developed through the concept of the individual situation.
\end{abstract}

KEYWORDS: Religious exemption, fundamental rights, private law interpretation, subjective situation.

RESUMEN: La exención religiosa en los Estados Unidos es brevemente analizada por los efectos de su carencia conceptual, sobre el sistema y su ámbito operativo. La aplicación en el derecho privado, en cuanto fase de la interpretación que desarrolla el control sobre los efectos de las normas y la taxonomía de los ámbitos, aún más resalta estos efectos a nivel sistemático. El enfoque iuprivatístico permite evidenciar el desplazamiento conceptual que se genera por parte de la Primera Enmienda en relación a otros ámbitos aplicativos y la función de clasificación que, con respecto a la exención, puede ser desarrollado por medio del concepto de situación subjetiva. 
PALABRAS CLAVE: Exención religiosa, derechos fundamentales, interpretación en derecho privado, situación subjetiva.

\section{INTRODUCTION}

Prolegomena. Religious exemption. Aspects of its problematic framework.

Patriae, percussae et indomitae.

"Ergo age, care pater, cervici imponere nostrae;

ipse subibo umeris nec me labor iste gravabit;

quo res cumque cadent, unum et commune periclum,

una salus ambobus erit. Mihi parvus Iulus

sit comes, et longe servet vestigia coniunx".

In this article we try to highlight some problems among that may be reputed essential in the interpretation of contemporary private law, connected to the application of fundamental rights and to the Rechtsfortbildung that follows it (Heck, 1914, p. 179; Larenz, 1975, p. 366), meant both as an activity, the formation of the law through the application by the courts and interpretation, and as its systematic achievement.

This issue is of general relevance today, beyond the single national system (Quint, 1989; Friedmann and Barak-Erez, 2001; Canaris, 1999, p. 360), but the ratio of the particular relevance of the Free Exercise Clause of the US system, especially about the institution of exemption, is due to a sequence of concurring peculiarities that describe its problematic conjoint. Among them, the nature of its recognition and the position in the hierarchy of sources of law, that is, the form of freedom and the constitutional rank it covers. It follows the general application in the system, rooted in protection also on a subjective or individual basis and implemented through the judiciary application model (Barak, in Friedmann and Barak-Erez, 2001, p. 25) therefore primarily by interpretation. The taxonomic profile that is the lack of 
conceptual configuration is also particular, also concerning the - more reduced - modern expectations of the ordering value of the concepts (Begriffsbildung, Larenz, 1975, p. 20), an element mainly due to the stable adoption of a self-restraint position of the Supreme Court with respect to the determination of Religion (Greenawalt, 2006, 125).

The profile of the systematic context is equally essential. It consists of the link between recognition of freedom of religion and coessential recognition of the pluralistic nature of American society and the law system. These commonly adopted arguments can be summarized - inter multos - from the Justice O 'Connor dictum (Concurring, in McCreary County v. ACLU of Kentucky): «[...] the goal of the Clause is clear: to carry out the Founders' plan of preserving religious liberty to the fullest extent in a pluralistic society».

Therefore, the relevance of the religious exemption can be outlined according to the first data highlighted here: a privilege recognized to a subject or group of subjects concerning the general applicability of the law. Under the application of a constitutional principle, about which, however, the interpreter is not able to provide ex-ante the normative elements and characters, from this perspective of the Rule of Law, the common criticism towards the application of this institution as a violation of the fundamental principle of equality of subjects before the law. From the perspective of private law, however, it can be highlighted how exemption entails further and equally radical incompatibilities.

\section{I) RECHTSFORTBILDUNG AND PRIVATE LAW}

The formation of private law through interpretation and the application of fundamental rights are guided by criteria abstractly common to other areas of law but which peculiarly take place. Here it is necessary to refer more widely to traditional studies on legal hermeneutics (Larenz, 1975, p. 204; Canaris, 1968, p. 55; Betti, 1990, p. 157) and to highlight - succinctly - the nature and function of the process of application of the rules by 
interpretation. This phase completes the interpreter's activity, following the phases of Comprehension and Interpretation and giving rise to a peculiar dialectical process that completes the entirety of the hermeneutic process (Larenz, 1975, p. 211).

A consequence of the principle of ratio decidendi is that the application does not only concern the concrete case but also the function of interpretation regarding the overall system and, more strictly, the taxonomic function of coherence with the contextum traditum (Larenz, 1975, p. 209), that is the application field (Anwendungsbereich) where it produces efficacy for reasons of similarity of the concrete case.

Legal principles govern this field and, for the evolution of the system, are superior to the particular rules and into it, therefore. There it can be no evaluation of contradictions (Larenz, 1975, p. 336). These principles are coherent with each other. They are mutually complementary and self-restrictive. They can regulate jointly, prevail in any case, or cede the normative function in another case (Zusammenspiel, Larenz, 1975 , p. 475). The decision must be supported by a ratio that avoids fallacies such as, for example, the logical contradiction, and which also guarantees the objective compatibility and concordance of the evaluation she expresses. In other words, the systematic control over the decision requires that the concrete rule be inspired by the principle of coherence, concerning the legal system and the application field outlined by the similarity. The attraction in a field must be considered integrated when the similarity between clear cases is such that it is impossible to identify a ratio decidendi for a different treatment between them, on the contrary generating an obligation for the interpreter to «treat as equal what is equal» (Larenz, 1975, 359).

The area of evaluation about similarity is the concordance between some of the essential elements of the cases assumed in the perspective of the decision, although other elements are dissimilar.

As can be seen, at this level of interpretation in a broad sense, the application plays an independent role concerning the hermeneutic phases that precede her. It represents the 
rootedness in the concrete case of the decision. However, with the judgment of similarity and the evaluation of coherence of the decision, it also identifies the ratio of the principle of equality in the application, both concerning the field's context and the system in general.

\section{II) OBJECTIVE PLURALISM AND INTERPRETATION}

In 1947 the Supreme Court, by the Everson case, recognized as religion in the context of the First Amendment practiced widespread in the United States that were not part of the tradition dating back to the Constitution. The multireligious presence is subsequently recognized several times, both in the legislation and in the Courts. However, this data does not seem suitable to conceptually exhaust what must be identified with pluralism («pluralistic society») as in the dictum, as mentioned above of Justice O'Connor.

A pluralist system, more widely, recognizes and protects a plurality and heterogeneity of fundamental values, for example, by recognizing them as rights or as freedoms. It also recognizes and protects their different forms of implementation and exercise. The pluralistic legal system, as such, is not structured in a hierarchical form (Larenz, 1975, p. 331) and therefore recognizes that conflicts between values (or between their forms of implementation and exercise) cannot be resolved based on a pre-existing hierarchy.

The system assumes that they are characterized by incommensurability (Larenz, 1975, p. 400), that is, lacking an objective attitude to measurement through methods that the system can recognize as known and objective, despite to the use of interpretative allegories such as weighting (Abwägen) or weighing (Gewichten).

By assuming the pluralism of values, conceptually, as objective pluralism, we intend to highlight that these properties are rooted in the epistemology of the system, being essential elements of the interpretation that concerns it (Tolone Azzariti, 2006). 
On the matter of application, the objective pluralism involves, as a significant effect of the interpretation, the plural recognition of the similarity between the cases, also falling within areas determined by different values, where there is an eadem ratio juris. Therefore other is not identifiable that justifies a different treatment.

\section{III) TAXONOMIC FUNCTION OF PRIVATE LAW INTERPRETATION}

These data are constitutive. Private law science, concerning the application of fundamental rights, must naturally deal with establishing, mainly by interpretation, the rules of exercise and implementation within its fields of application and in coherence with them, in other words, focus the problem of consistency and congruence of ratio decidendi to the concrete case: a control simultaneously exerted both on the case and the system. It is evident that freedom of religion like other fundamental rights (in the United States, in Common Law in general and the systems of Civil Law) has effectiveness in a concrete case hence that takes place within different spheres, characterized by specific rules and institutions, and that for each of the interpretation of this field must produce a consistent decision. An example is the mittelbare Wirkung in the German BGB: the effectiveness in the context of contracts and obligations incorporates a specific conformation, mediated by the general clauses. The application takes the form that makes it consistent with the rules and principles governing the field (Röthel, 1968, p. 48; Larenz, 1975, p. 216; Tolone Azzariti, 2020, pp. 305 ss.) according to the principle of interaction of effects or mutual effect (Wechselwirkungslehre). The principle also works when the Supreme Court interpretation's superseding effect is focused (Quint, 1989, p. 273). In order for the Constitution to take effect within private law and a private dispute between subjects, corresponding state action must be primarily identified. When this occurs, the system provides to the total replacement by the private law doctrines drawn up in the specific jurisprudence of the Supreme Court, and it is also in these cases that the balance between consistency and individualized considerations linked to the case is rewarded (Epstein et al., 1998, p. 802). 
In this sense, interpretation is a constitutive element of the fields' taxonomy (Birks, 2000; Sherwin, 2009, p. 28) and a function of the relevance of its value in contemporary private law. In a context where the sources of decision and the rule are manifold, from private autonomy to the fundamental norms of the system, concerning a constant, necessary clarification of the concepts and rules, the classification and differentiation of the application's fields, according to the degree of determination of the content provided by the interpretation, is an element of certainty in the concrete case, of predictability of the system, rules through the differentiation of concepts and abstract cases. In other words, the taxonomic function of interpretation is an essential function of the legal order.

\section{IV) SUBJECTIVE SITUATION. UNINTENDED EFFECTS OF INTERPRETATION AND BEGRIFFSVERDRÄNGUNG}

Some findings follow from what has been reported so far. The first concerns the interpretation of subjective rights and leads to the question of taxonomic coherence and the solution through the notion of the subjective situation. It has a more abstract character but, in our opinion, a higher conceptual accuracy since it can reflect the heterogeneity of the sources of rule (private will, private autonomy, legal system), which, with different intensity case by case, concur to define the concrete subjective situations. (Roubier, 2005, p. 60)

In the doctrine and jurisprudence dedicated to the topic in question, it is argued almost exclusively around the concept of right (right of exemption) as an effect of the application of the Free Exercise Clause, but it seems clear that the use of this term must be considered as lacking the foundational suitability of the concept.

On the contrary, it is necessary to assume the interpretative result for each private law field. Then where the application intervenes and having regards to the plurality of concurring sources and their different nature, is not necessarily that of the configuration of a right but instead is resolved through different subjective situations having different legal features 
and content. While the interpretation in decisions outlines case by case faculties, powers, parental authority, individual rights, inalienable rights, obligations, responsibility, it seems incongruent to call these distinct situations as right without focusing on their differences. This complexity of situations arises, in turn, from the interpretation that generally must take into account, as a minimum, not only the effectiveness of an abstract constitutional rule but also the pre-existing discipline in the field of application and the nature of the rule concerning which an exemption is requested, especially following her compulsory degree.

The second observation concerns the effects of the interpretation of the constitutional rules. Within an experience common to different systems (Strauss, passim), they naturally involve the historical recognition of norms and their organic development over time. However, in our opinion, it is necessary to assume the evidence that, nevertheless, the Rechtsfortbildung gives an objective and referring to present time determination of the rule that emanates from these norms: this relief, therefore, concerns the unintended effects of interpretation of the legal text, whatever this text is and any considered constitution (Larenz, 1975, p. 34; Betti, 1990, pp. 801 and 816; Brütt, 1907, p. 62; Heck, 1914, p. 38; Menger, 1883, p. 153). The interpretative process that generates unintentional effectiveness can be summarized as follows (Tolone Azzariti, 2020, 274). First of all, the recognition of a norm and its ratio as well as its applicability in the present time concerning tempus promulgationis, therefore, concerning changed systematic circumstances. The adaptation of the ratio to the organic, present context follows, and the observation that the precept and the concepts norm contains can have a distinct position concerning the original. Among the effects of this interpretative operation thus there may be a conceptual displacement (Begriffsverdrängung) when this interpretative adaptation must point out that the field governed initially through a concept or a norm has been attracted and is governed by other concepts or by other norms, because of subsequent legislation or because the interpretative options of the Courts have produced this result. (Betti, 1990, p. 823) 
In our opinion, the field of religious exemption is characterized by such an interpretative phenomenology for which we proceed to give an account of it.

\section{INSTITUTIONS}

\section{V) CONCEPTUAL DEFICIENCY AND ATTEMPTS OF FOUNDATION}

Following a systemic approach (Tolone Azzariti, 2020, 311) we can recall that in Ballard case Justice Jackson, in his dissenting opinion, indirectly raised the concept foundation issue about religion: «[...] how we can separate an issue as to what is believed from considerations as to what is believable» (the United States v. Ballard, 1994). The issue, which stems from the stable Supreme Court self-restraint position, is symptomatic of a problem and needs latent in the application of the exemption rule, which also manifests itself through attempts at the conceptual foundation in doctrine and jurisprudence. A problematic framework that has, among others, the following characteristics: the conceptual deficiency concerning the notion of religion, the consequence of a field characterized by taxonomic asymmetries, the application extension to different fields and the unjustified regulatory attraction of them, the irrelevance of equality in the application of the ratio decidendi to cases with similarity characters.

In our opinion, these elements are a demonstration of an option's effect in a matter of interpretation (the self-restraint position especially by the Supreme Court), the effect of a conceptual displacement that the Religion field's indeterminacy implements concerning Conscience and which is rooted in the origins of the Constitution. In particular, it has genesis in the final approval of the text, which does not recognize, as some previous Drafts did, the Freedom of Conscience. The displacement takes place in the contemporary interpretative system by catalyzing cases of subjective situations of absolute heterogeneity in the no-taxonomy field of religion. 
The problem, the taxonomic indeterminacy, is commonly detected («[...] it means everything and nothing» (Laycock, 1986, p. 450). However, the consideration that it is believed to be provided to it in doctrine is different.

Among the scholars who focus on the essentiality of the problem (Greenawalt, 1984) - two different methodologies aimed at the conceptual foundation are proposed, one of a primary type and one of a pseudo-analogical nature. Both are intertwined with the fundamental question: when it is possible to grant a religiously justified exemption and upon which legal ground.

\section{VI) BEGRIFFSBILDUNG. STRUCTURAL HYPOTHESES. STATUS AND BELIEF}

The doctrine (Greenawalt, 2008, p. 301; Greenawalt, 1984, p. 756) hypothesized a foundation of the concept of religion and therefore of the tokens (fattispecie concrete) related to it, among which the exemption, though certain elements, that can be assumed for this function autonomously or in a concurrent form.

The critical elements that seem identifiable are the following.

The first element is status in itself, a status religionis if we adopt a pseudo-concept. Unlike in the regular use of status juris, its assumption and abdication, as well as the configuration of the concrete situation quoad effectum, are based on the mere will of the subject, without the presupposition of any institutional recognition and the ordering mediation by an equally recognized collectivum (Tolone Azzariti, 2020, 313). In short, the entitlement of this "status" results in membership without any legal form, which is recognized ex-post in the jurisdiction.

Having a belief or a modus cogitandi is a constantly reaffirmed element, for example, by the recognition to be granted to Honest Conviction and Sincere Beliefs (Burwell case; Greenawalt, 1984, p. 762) defining a context where problems 
related to the conceptual deficiency emerge in blunt forms. From Ballard's case onwards, there are strict criteria on cognition and her limits. A jury cannot receive instructions that imply external cognition of the beliefs that are called upon to examine. The criteria for recognizing the alleged religious beliefs are exclusively internal to the area of the psychological element: the belief of the case is relevant or not based solely on the honest conviction and sincere belief criteria. This discipline not only removes ordinary cognitive criteria (reasonableness; truthfulness) but also at the root cognition power. Another limit is opposed to the evaluation of essentiality or marginality, in the individual moral system or the collectivum one, of the belief object of evaluation, as already in the famous Smith and Lee cases.

In light of these considerations, breviter dictum, in our opinion, the application is left to a cognition activity, in the course of rules' concretization, that is conducted sine praevia regula. Knowledge about the relevant facts of the case (Tatfrage, Larenz, 1975, p. 262) is by necessity developed arbitrarily; both within the "status" and the psychological element, it assumes de facto the power to establish which of them should be assumed or not to a judgment of constitutional relevance. This process, by integrating the normative content, is placed (ex-post) not in the application phase of the norm, but it is an understanding of meaning and sense (Vorverständnis).

\section{VII) METHODOLOGICAL HYPOTHESIS. EXEMPTED AC- TIVITY AND PSEUDO-ANALOGY}

The examination of the conceptual foundation assumes an even more relevant systematic value when it concerns an activity, the protection of an activity because it is an exercise of religious freedom. The system is affected as a whole for the pieces of evidence already exposed: a pluralistic order, when the character of similarity is identified in a token recognized in one field of application, extends the recognition and protection also in different fields delimited by the implementation of other constitutional rules. 
The method, proposed in doctrine and jurisprudence, had two theoretical approaches, Single-Factor and Multifactor, which followed each other critically and have been formulated with appreciable caution for adaptation to problematic circumstances (Greenawalt, 1984, p. 763). This methodology had an application sequence in jurisprudence, regarding the Church of Scientology, and a theoretical acme in Malnak v. Yogi case thanks to Judge Adams' concurring opinion. However, the incompatibilities with the formulation of the process of integration by legal analogy are evident, and the effects of the conceptual deficiency and the indeterminacy of the field are even more evident. (Tolone Azzariti, 2020, p. 328)

The pseudo-analogical syllogism founds the major premise on elements detected by religions already recognized as such; these are the beliefs in "Extratemporal Consequences," "Ultimate Concern," "Higher Reality." However, they are not assumed according to conceptual expectation and function, by implementing a Begriffsbildung process, they are selected by a praxeological approach based on cases indisputably recognized and then extended to doubtful cases to find, ad includendum, their eventual presence and therefore consider the token assimilable to the notion.

In addition to what appears to be, methodologically, a violation of the Establishment Clause, the limits also appear by the internal perspective, contradictory even when not interested in the taxonomic issue. In the absence of the foundation of the primary class of syllogism (Obersatz), alignment with the selective criteria is over-inclusive concerning certain phenomenologies and is underinclusive concerning others (Greenawalt, 1984, p. 773), hence the need to modify the approach.

The multifactor version intends to respond to this problem - asymmetry of inclusiveness - but it does so through totally abdicating the founding function: «[...] no single factor is essential» (Greenawalt, 2006, p. 137) and proposing family resemblance among a full group of elements, borrowed from the recognized cases, as a normative criterion. None of them would have constitutive character, and the extension by pseudo- 
analogy would occur by identifying one of them by the belief object of judgment.

The absence of a regulatory function is evident, as there are no limits to an ad libitum proliferation of the cases.

\section{VIII) CONCEPTUAL DISPLACEMENT AND CONSCIENCE}

As part of the attempts to establish the notion referable to the First Amendment, two arguments that seem to contradict each other coexist.

The belief in Supreme Being, as an essential element, is removed as restrictive of the concept in an unjustified manner, despite the more excellent proximity to the framers' original intent (Torcaso case). On the contrary, the scrutiny of "doubtful" beliefs takes place based on elements found in already recognized beliefs. Beyond the theoretical model, the procedure is not considered to be in contrast with the Establishment Clause, although the selection of the elements adopted as criteria affects the structural level of the beliefs (Esbeck, 2000, p. 315).

The conceptual issue that not seems relevant to the Supreme Court, with all its systemic implications summarized above, appears today to be completely marginal. The physiognomy of the Free Exercise Clause, following the modern jurisprudential evolution, outlines a regulatory model within which the religious qualification and the definition of the application field have residual normative value.

The Seeger case initiates the protection of the parallel positions of military objectors, based on the Clause, for those who maintain «devotion to goodness and virtue for their sakes, and religious faith in a purely ethical creed.» The Supreme Court then granted the exemption recognizing beliefs «sincere and meaningful [that] occupies a place in the life of its possessor parallel to that filled by the orthodox belief in God of one who qualifies for the exemption.» With the Welsh case, the parallelism with religion also becomes superfluous, and grant exemption recognizes the importance of personal moral code 
(«scheme of things») not necessarily shared by anybody or objectively detectable, as will be confirmed in the Gillette case.

It seems clear that the application assumes religious belief, however, identified only as one of the defining elements of the field but not the only one. There is a normative absorption of fields related to individual free morality, which, very roughly, can be called Conscience. However, the perspective of the subjective juridical situation can facilitate greater precision.

\section{CONCLUSIONS}

\section{Subjective situation and the complexity of sources. The concrete form of conceptual displacement}

The evolution of the normative field makes conceptual displacement clear, but a more precise picture in its complexity could derive from the focus of subjective situations. (Tolone Azzariti, 2020, p. 342)

When the Supreme Court recognizes the existence of a «Zone of conscience and belief,» as in Casey's case regarding abortion, at the same time provides a series of limits that condition her existence, modus procedendi, and limited efficacy. The termination of pregnancy can only be protected through this situation and the scheme connected to it: in these cases, she has the faculty's configuration, not of a right. The adopted formula "zone of conscience and belief» is general only literally, the limits to its effectiveness and the conditions of existence and validity are coessential to the formulation.

For another example, the exemption profile in the Yoder case qualifies and is strictly relevant within a situation of parental authority. The decision formulas that make the difference between "ways of life, however virtuous and admirable [...] based on purely secular considerations» and what is instead recognized to the appellant that is «not merely a matter of personal preference, but one of deep religious conviction, shared by an organized group,» cannot be read functionally disengaged from the subjective situation on which they rely, that is the appellant's parental authority and the 
substitute power that in education matters is claimed by the State: «The State's claim that it is empowered, as parens patriae $[\ldots] »$.

In the recognition activity, the "formal structure" of religion is constant: appellant is qualified through her subjective assumptions, therefore not in terms of individual but terms of relational "status" and concerning beliefs, even when a relational structure is entirely absent, as in the case of agnosticism, skepticism and atheism (Greenawalt, 2006, p. 152). The recognition of vague notions of vague beliefs dissolves the abstract complexity of juridical situations related to liberties and of their effects; even their components of duties and obligations disappear within incompatible assimilation between freedom of religion and freedom in general. (Sandel, 1989, p. 614)

The proposals in doctrine are consistent with this structure. A pluralistic interpretation would call for the recognition of the same situations, when characterized by similarity, in different fields. On the contrary, it is asked to consecrate religion as a "larger issue» (McConnell et al., 2016, p. 226) suitable to absorb within her field, devoted to indefiniteness, also «culturally rooted practice» (Greenawalt, 2008, 304) or the situations when «the individual sincerely holds that belief with the strength of traditional religious views.»

About the situation that has termed parallel position, in Seeger and Welsh cases by a statutory creative interpretation, other elements should deserve more consideration. In our point of view should be more emphasized that the exemption is granted as an extension of an already recognized and applying for a position, by the legislation of Universal Military Training and Service Act, that is the exemption provided regarding objectors because "of their religious training and belief.» Another element that could be considered relevant would be the special duty for which the exemption has been issued, a military duty, involving primary moral values, in a unique historical moment like 60's years because of the war in Vietnam. Although the interpretative procedure is not exhaustive with regards to juridical form, it would be relevant to assume the degree of 
binding of the norm and her effect on the specific subjective situation, by the type of compulsion exercised. As a result, the activity required by the recipients. It can identify a protected subjective right by highlighting, in the field of privilegium, the equivalence of these subjects to holders of recognized religious status.

In conclusion, having dissolved the limits of the field and blunted the powers of cognition, it can be said that the subjective situation can provide a non-normative criterion but at least useful on the mere classification level. The recognition of the exemption, even outside the abstractly proper field, can be somehow cataloged following the complexity of the regulatory situation.

First of all, concerning the nature of the normative source for which by exemption non-application is requested (normative cogency, the scope of application); the preexistence of a legislative or jurisprudential recognition also seems relevant, hence that the object of the decision is the extension or not of an already recognized exemption. The legal values and interests involved appear to be relevant, at least by more general classification, if exemption concerns personal or patrimonial goods and interest, where the notion of exercise concerning belief is substantially left to the determination without control of the subjects involved. The limitation to the personal and collective legal sphere -in the case of a religious group-, which the rule would entail following the appellant's claim.

The protection extends ultra ambitum when more than ratio juris changing reasons for public policy suggest so.

An area outside the law.

\section{BIBLIOGRAPHICAL REFERENCES}

Betti, E. (1990). Teoria generale della interpretazione, (vol. II). Milano: Giuffré.

Birks, P. (2000). English Private Law, (vol. I). Oxford: Oxford University Press. 
Brütt, L. (1907). Die Kunst der Rechtsanwendung. Zugleich ein Beitrag zur Methodenlehre der Geisteswissenschaften. Berlin: J. Guttentag.

Canaris, C. W. (1968). Systemdenken und Systembegriff in der Jurisprudenz. Berlin: Duncker \& Humblot.

Canaris, C. W. (1999). L'incidenza dei diritti fondamentali sul diritto privato tedesco. Studium Juris, (p. 359-370).

Conkle, D. O. (2016). Religion, Law, and the Constitution. St. Paul: Foundation Press.

Epstein, L., Hoekstra V., Segal, J. A., and Spaeth, H. J. (1998). Do Political Preferences Change? A Longitudinal Study of US Supreme Court Justice? J. Politics, 60(3), (pp. 801-818).

Esbeck, C. H. (2000). Differentiating the Free Exercise and Establishment Clauses, J. Church \& St., 42, (pp. 311-334).

Friedmann D., Barak-Erez D. (eds.) (2001). AA. VV., Human Rights in Private Law. Oxford-Portland: Hart Publishing.

Greenawalt, K. (1984). Religion as a Concept in Constitutional Law, Cal. L. Rev., 72, (pp. 753-816).

Greenawalt, K. (2006). Religion and the Constitution (1st edition). Princeton: Free Exercise and Fairness, Princeton University Press.

Greenawalt, K. (2008). Religion and the Constitution, (2nd edition), Princeton: Establishment and Fairness, Princeton University Press.

Heck, P. (1914). Gesetzesauslegung und Interessenjurisprudenz, AcP, Bd. 112, (pp. 1-318).

Laycock, D. (1986). A Survey of Religious Liberty in the United States, Ohio St. L. J., 47, (pp. 409- 451). 
Larenz, K. (1975). Methodenlehre der Rechtswissenschaft. Berlin-Heidelberg-New York: Springer Verlag.

Mcconnell, M. W., Berg, T. C., and Lund, C. C. (2016). Religion and the Constitution ( $4^{\text {th }}$ edition). New York: Wolters Kluwer.

Menger, K. (1883). Untersuchungen über die Methode der Sozialwissenschaften, und der Politischen Ökonomie insbesondere. Leipzig: Duncker \& Humblot.

Quint, P. E. (1989). Free Speech and Private Law in German Constitutional Theory. Md. L. Rev., 48, (pp. 247-349).

Röthel, A. (1968). Normkonkretisierung im Privatrecht. Tübingen: Mohr Siebeck.

Roubier, P. (2005). Droits subjectifs et situations juridiques. Paris: Dalloz.

Sandel, M. J. (1989). Religious Liberty - Freedom of Conscience or Freedom of Choice. Utah L. Rev., (pp. 597-615).

Sherwin, E. (2009). Legal Taxonomy, Legal Theory, 15, (pp. 25$54)$.

Strauss, D. A. (1996). Common-Law Constitutional Interpretation. U. Chi. L. Rev., 63, (pp. 878-935).

Tolone Azzariti, S. (2006). Diritto private globale, Objective Pluralism e libertà di religione. Cosenza: Luigi Pellegrini Editore.

Tolone Azzariti, S. (2020). La interpretación de la exención religiosa en la perspectiva de la situación subjetiva de derecho privado. Efectos irreflejos de la carencia conceptual y desplazamiento normativo en la libertad de religión de los Estados Unidos de América. Pensar en Derecho, 15, (pp. 263 - 372). 


\section{TABLE OF CASES.}

\section{Supreme Court}

Burwell v. Hobby Lobby. (2014). 573 US 682.

Employment Division v. Smith. (1990). 494 US 872.

Everson v. Board of Education. (1947). 330 US 1.

Gillette v. the United States. (1971). 401 US 437.

Mc Creary County, Kentucky v. ACLU of Kentucky. (2005). 545 US 844.

Planned Parenthood v. Casey. (1992). 505 US 833.

Torcaso v. Watkins. (1961). 367 US 488.

United States v. Ballard. (1944). 322 US 78

United States v. Lee. (1982). 455 US 252.

United States v. Seeger. (1965). 380 US 163.

Welsh v. United States. (1970). 398 US 333.

Wisconsin v. Yoder. (1972). 406 US 205.

\section{Lower Courts}

Malnak v. Yogi. (1979). 592 F. 2d 197 (3d Cir.) (per curiam).

Received: 22/04/2020

Approved: 16/06/2020

Salvatore Tolone Azzariti: Professor of Civil Law, Oxford University, University of Buenos Aires and University of Palermo.

Correo electrónico: stolon@palermo.edu

City: Naples/Oxford

Country: Italy/United Kingdom 
